\title{
Identification of Medicinal Plants in the Ciudad Universitaria (Madrid): new data from microscopic observations
}

\author{
Laure-Anne Peyrat, Monika J. Trawinska \& Rosario G. Gavilán (*)
}

\begin{abstract}
Peyrat, L.A., Trawinska, M.J. \& Gavilán, R.G. Identification of Medicinal Plants in the Ciudad Universitaria (Madrid): new data from microscopic observations. Lazaroa 33: 199-206 (2012).

A study of medicinal flora is currently under way at the Ciudad Universitaria (Madrid), based on a previous study of flora in which 416 plants were compiled. We have selected plants with a therapeutic use collected in the study area which have been identified both macroscopically and microscopically using the appropriate tools. This paper presents a complete description of eleven taxa.
\end{abstract}

Keywords: medicinal plants, Spain, flora, histological and anatomical observations.

Resumen: Peyrat, L.A., Trawinska, M.J. \& Gavilán, R.G. Identificación de plantas medicinales de la Ciudad Universitaria (Madrid): nuevos datos sobre observaciones microscópicas. Lazaroa 33: 199-206 (2012).

Se está desarrollando en la actualidad un proyecto sobre la flora medicinal de la Ciudad Universitaria de Madrid, a partir de un estudio previo de la flora en la que se recogieron 416 taxones. Se han seleccionado de dicho catálogo florístico aquellas que tienen uso terapéutico y, posteriormente han sido recolectadas en el área de estudio e identificadas tanto macroscópica como microscópicamente utilizando las herramientas apropiadas. Se presenta en este trabajo la descripción completa para once taxones.

Palabras clave: plantas medicinales, España, flora, observaciones histológicas y anatómicas.

\section{INTRODUCTION}

The Ciudad Universitaria is an area of 400 ha located in the northwest of Madrid. The plans to create a space for research and the development of advanced studies in this area date from 1927, when it was first designed. Later in 1983 it was declared a 'Historic and Artistic Site' by the Spanish government, and a 'Site of Cultural Interest' by the Madrid Regional Government in 1999. The space is shared jointly by two universities (Complutense and Politécnica) and several research and technical institutes (CSIC, CIEMAT, AEMET). Now a project is being developed to bring together all the objectives of these institutions in order to transform the current campus into a genuine 'Campus of Excellence'.
The learning practices of life- and healthscience students makes the Ciudad Universitaria an interesting and suitable focus for different types of research into a range of flora, including both medicinal flora and vegetation. It is also suitable for other types of studies that focus more on urban ecology, since it still has semi-natural areas that have been reduced in recent years due to the construction of new buildings to attend to the new administrative, research and study needs of the institutions. The area is thus subjected to anthropic pressure, and its present flora is rich in ruderal, nitrophilous plants. The flora is somewhat unstable, as there has been a recent increase in the fluctuations caused by infrastructure works and land clearing. The presence of alien plants growing in the gardens and lawns of the campus also

* Departamento de Biología Vegetal II. Facultad de Farmacia. Universidad Complutense. E-28040 Madrid. Email: rgavilan@ucm.es 
accounts for the increase in the number of taxa, as in some cases they become naturalized, either due to the unintentional introduction of diasporas with seeds and fertilizers used in gardening, or spills land on lawns bringing typical plants of Cynosurion (Molinio-Arrhenatheretea).

To ensure the reproducible quality of herbal products, proper control of the starting material is essential. In recent years there has been a certain emphasis on the standardization of medicinal plants, since according to the World Health Organization (WHO), the macroscopic and microscopic description of a medicinal plant is the first step towards establishing its identity and purity and should be carried out before any tests are undertaken. It is essential to establish systems for inventorying and maintaining the status of medicinal plants, as there are so many medicinal species that their conservation is a very important issue inside plant conservation as a whole (HAMILTON, 2004). The fact that a species is used as medicinal in one place but not everywhere and at all times is especially significant in a city -such as Madrid in general, or the Ciudad Universitaria in particular- as in large cities people do not tend to harvest them, but view them with greater fascination than other facets of Botany. Thus the category of 'medicinal' for a particular group of plants that need to be conserved as special should be made similarly to the way in which plant conservationists classify plants as 'endangered', but which lacks any special significance to other people (AKEREKE \& al., 1991; BODEKER, 2002). Their correct botanical identity based on external morphology is possible and absolutely necessary when a complete plant specimen is available (SULTAN \& al., 2010). Anatomical characters can also help with identification when morphological features are indistinct (CUTLER \& al., 2008).

The only study available on the medicinal flora in this area is a work by GAVILÁN \& al. (1992) identifying plants from the Ciudad Universitaria and containing a compilation of 416 taxa. There are other works that mention plants in the city of Madrid or in the areas surrounding the Ciudad Universitaria (IzCO, 1979; GARCÍA ANTÓN \& GÉNOVA Fuster, 1985; IzCO \& PANGUA, 1986), sometimes focusing on exotic flora (Molina \& al.,
1991; Gavilán \& Molina, 1992). We have used the flora of the Ciudad Universitaria (GAVILÁN \& $a l ., 1992)$ to make a selection of plants with therapeutic use and then to collect them for macroscopic and microscopic identification using the appropriate bibliographic tools (CASTROVIEJO \& al., 1986-2010; TUTIN \& al., 1964-1993; ANON., 2007-2010).

\section{MATERIALS AND METHODS}

All the plants presented were harvested in the spring of 2012 in the Ciudad Universitaria. The detailed sampling area for each plant is indicated below. We sampled three areas: areas close to the 'Alfonso XIII' Botanical Garden, the area around the allotments at the Agricultural School, and a third area around the Dehesa de la Villa stream.

We collected material for the purpose of both macroscopic and microscopic identification. In the first case we collected the complete individuals following the usual practice in this kind of work, which were then dried (by press) and identified. Voucher specimens were then prepared and deposited at the MAF herbarium as reference materials. For determination of taxa we followed Flora iberica and Flora europaea (CASTROVIEJO \& al., 1986-2010; TuTin \& al., 1964-1993). For the microscopic identification we collected the parts of the plants that have therapeutic use. We cut and dried them in an oven at a temperature of $60^{\circ} \mathrm{C}$ for $24 \mathrm{~h}$. Then we used a grinder to reduce our samples to powder. They were examined using a solution of chloral hydrate which favours microscopic observation of the elements under study, as it makes them more transparent. An aqueous 5 / 5 concentrated solution was prepared, and a glycerine-jelly mounting medium for non-dehydrated preparations was chosen due to its simplicity and good results, since we set up the final preparations in a few minutes and maintained them over a long period of time. For the identification we followed the European Pharmacopoeia (ANON., 2007-2010), after drawings were made of the microscopic (anatomical or histological) characters to highlight various differential characters that could aid the macroscopic identification of each medicinal plant. 


\section{RESULTS}

\section{Compositae}

\section{Achillea millefolium $\mathrm{L}$. subsp. millefolium}

Madrid: Ciudad Universitaria. Facultad de Farmacia. Bordes de los céspedes cercanos al edificio, 22.05.1989, 28.05.2012, 664 m, Rosario Gavilán \& Laure-Anne Peyrat, MAF 171393.

Eurosiberian, herbaceous perennial plant that produces one to several stems with a rhizomatous growth form. It grows in temperate regions of the northern hemisphere and is indifferent to the substrata (PIgNATTI, 1982). In the Ciudad Universitaria we have found it in the boundaries of lawns around the Pharmacy building, although we have detected it growing in other locations on campus, usually close to freshwater. It was previously more frequent than now, when it can be considered almost rare.

The microscopic observation of the flowering top showed parts of leaves such as long hairs or the final segments of leaves with an ovate-lanceolate form that have a row of cells forming a connective tissue. We have also found parts of flowers such as corolla fragments formed by epidermis tissue, and round cells below. Pollen grain is typical of Compositae very thick echinate exine with short, acute spines (Figure 1).

\section{Silybum marianum (L.) Gaertner}

Madrid: Ciudad Universitaria. Campos de Agrónomos. Lugares incultos, descampados, bordes de los caminos entre los campos de cultivo, 13.06.2012, Rosario Gavilán \& Laure-Anne Peyrat, MAF 171391.

Annual or biennial herbaceous plant native to Europe that grows wild in southern Europe, northern Africa and the Middle East. It forms part of typical plant communities on soils that have suffered some turnover and present some levels of nitrogen, and are not very common on campus. We have found them in uncultured sites around

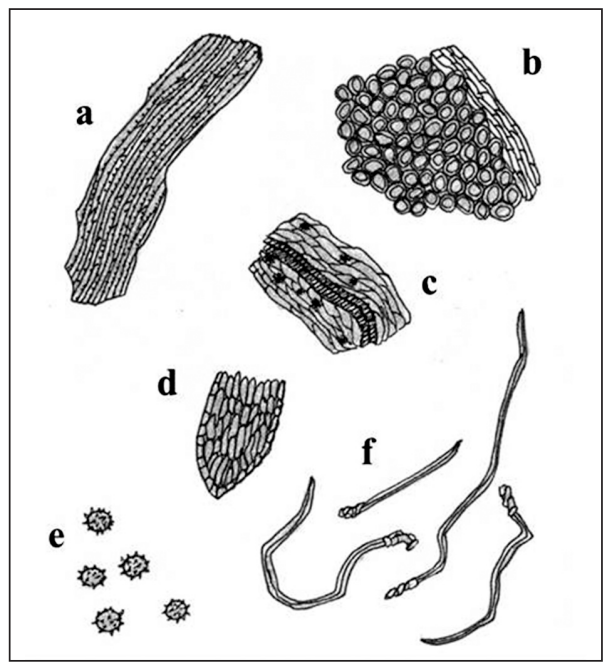

Figure 1. - Microscopic detail of Achillea millefolium flowering top powder: a, sclerenchyma; b, corolla fragment; c, oxalate druses in leaf tissue; $d$, connective tissue in leaf tips; e, pollen grains; f, hair with 5 basal cells.

the allotments run by the Agricultural School for students' practical exercises.

The microscopic observation of fruits showed parts of the fruit wall epidermis or the seed, including the embryo (Figure 2).

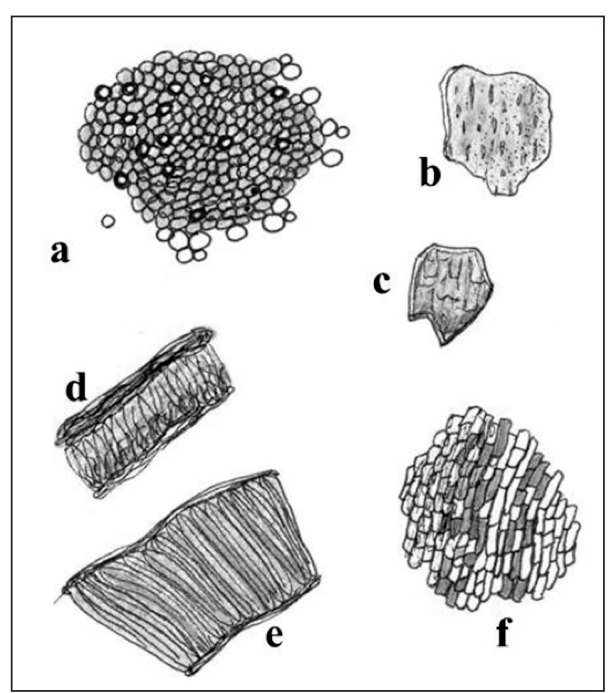

Figure 2. - Microscopic detail of Silybum marianum fruit powder: a, embryo with oxalate druses and oil balls; $b$, fruit wall epidermis; c, perisperm; d, fruit wall epidermishorizontal wall; e, testa palisade cells; f, pigment cells of the mesocarp. 


\section{Taraxacum officinalis F.H. Wigg.}

Madrid: Ciudad Universitaria. Facultad de Farmacia. Cespedes cercanos al edificio, 29.05.2012, 664m, Rosario Gavilán \& Laure-Anne Peyrat, MAF 171392.

We have followed the criteria of European Pharmacopoeia to describe the microscopic identification of our plants (ANON., 2007-2009), in spite of the taxonomic complexity of species included in Taraxacum Cass. (GALÁn, in press). In any case, and following Flora Iberica, the dandelion of the Ciudad Universitaria can be commonly seen in cultivated lawns; it is a robust plant not more than $25 \mathrm{~cm}$ in size, with pinnatisect leaves and saffron-yellow rays. However, there is another dandelion with low lobulated leaves, larger in size but also robust, that grows away from lawns and is more ruderal, and coincides with Taraxacum obovatum (Willd.) DC. There are also individuals with intermediate characters between both.

The microscopic observation of roots showed inulin droplets and latex, but also different parts of the parenchyma, including laticiferous channels or lignified vessels (Figure 3 ).

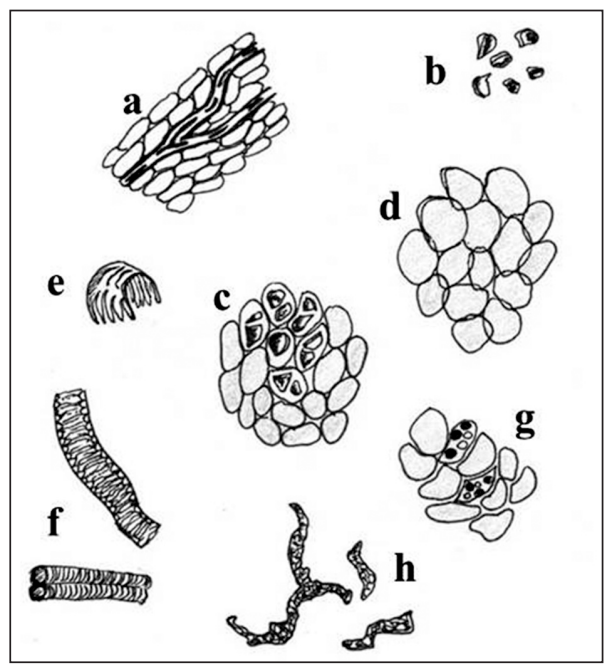

Figure 3. - Microscopic detail of Taraxacum officinalis root powder: a, parenchyma containing laticiferous channels, in longitudinal section; $\mathrm{b}$, inulin fragments; $\mathrm{c}$, f, lignified vessels; d, parenchyma; e, parenchyma cells containing inulin fragments; g, parenchyma containing laticiferous channels, in transverse section; h, latex.

\section{CRUCIFERAE}

\section{Capsella bursa-pastoris (L.) Medik.}

Madrid: Ciudad Universitaria. Campos de Agrónomos. Lugares incultos, descampados, bordes de los caminos entre los campos de cultivo, 13.06.2012, Rosario Gavilán \& Laure-Anne Peyrat, MAF 171384.

This is a very common, subcosmopolitan taxon, widely collected by students for their practical collections, since it does not show any kind of preference for soil type.

The microscopic observation of the flowering top showed parts of leaves such as star hairs, parts of flowers such as tricolpate, reticulate pollen grains and parts of fruit and seeds (Figure 4).

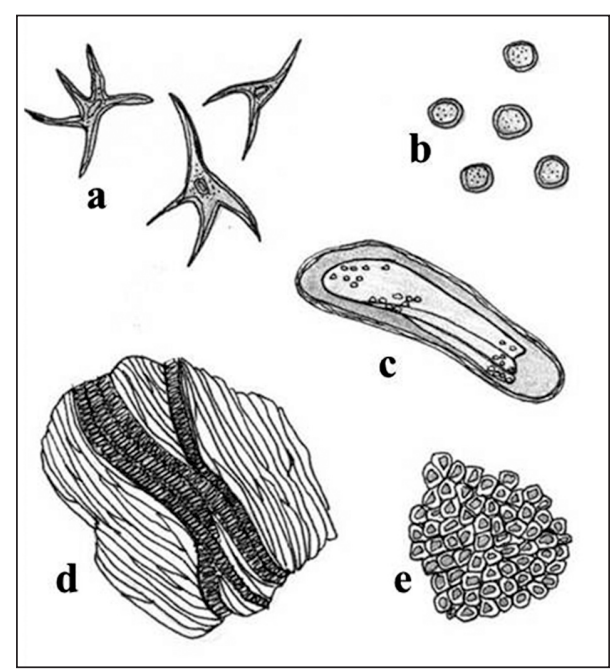

Figure 4. - Microscopic detail of Capsella bursa-pastoris flowering top powder: a, star hair; b, pollen grains; c, ovule; $d$, inner fruit wall; e, seed coat.

\section{GUTTIFERAE}

\section{Hypericum perforatum $\mathrm{L}$.}

Madrid: Ciudad Universitaria. Facultad de Medicina. Jardines abandonados al norte del edificio, 29.05.2012, 664m, Rosario Gavilán \& LaureAnne Peyrat, MAF 171387 
This is a subcosmopolitan shrub of medium height commonly found in the Ciudad Universitaria at the end of spring. It grows almost everywhere in Europe as far as eastern Russia, and is naturalized in many parts of the world.

The microscopic observation of the flowering top powder showed glands that are rich in hypericin, the active principle, fragments of anthers including pollen grains and part of epidermic tissue (Figure 5).

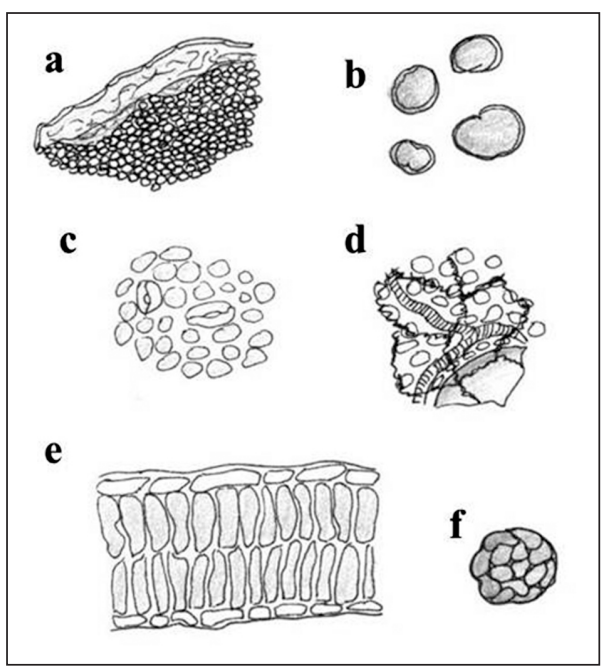

Figure 5. - Microscopic detail of Hypericum perforatum flowering top powder: a, anther lobe fragment with endothecium and pollen sac; b, pollen grains; c, lower leaf epidermis with stoma; d, upper leaf epidermis; e, palisade tissue; f, hypericin gland.

\section{LABIATAE}

\section{Rosmarinus officinalis $\mathbf{L}$.}

Madrid: Ciudad Universitaria. Facultad de Farmacia. Setos cultivados en los jardines cercanos al edificio, 29.05.2012, 664 m, Rosario Gavilán \& Laure-Anne Peyrat, MAF 171390.

Shrub with fragrant, evergreen, needle-like leaves and white, pink, purple or blue flowers, with a western Mediterranean distribution. It has been cultivated since ancient times all over the world (Morales, 2010). We have not found it in growing wild in the Ciudad Universitaria (GAVILÁN
\& al., 1993), but planted to form hedges, where it was collected.

The microscopic observation of the flowering top powder showed leaf star hairs, gland cells and parts of epidermis (Figure 6).

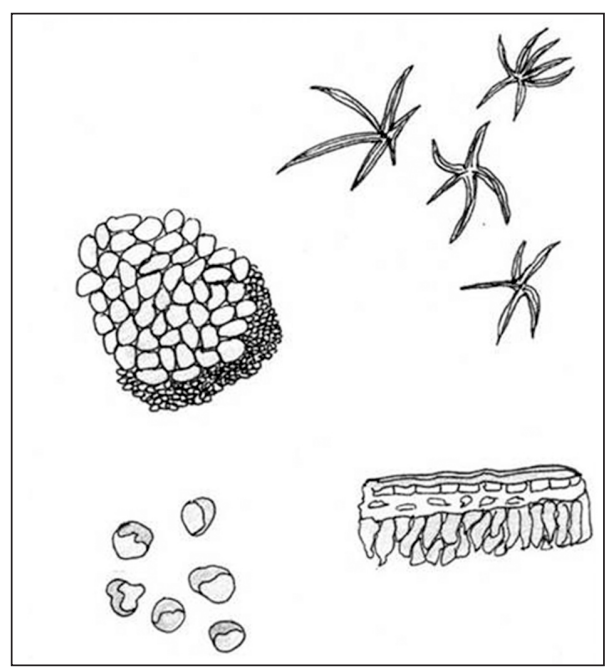

Figure 6. - Microscopic detail of Rosmarinus officinalis flowering top powder: a, star hairs; b, upper leaf epidermis; c, gland sheds; d, palisade tissue with collenchyma.

\section{MaLVACEAE}

\section{Althaea officinalis L.}

Madrid: Ciudad Universitaria. Jardín Botánico Alfonso XIII. Bordes de la valla del jardín, 664m., 20.06.2012, Rosario Gavilán \& LaureAnne Peyrat, MAF 171383.

Subcosmopolitan perennial species with a strong root and erect stems of $1.2 \mathrm{~m}$ which die down in autumn. The leaves and the root of this plant have medicinal properties.

The microscopic observation of the root powder showed starch grains, cells rich in mucilage, fibres and parenchyma with bundles, including vessel fragments. The observation of leaves also showed star hairs, Puccinia malvacearum teliospores and parts of epidermis and vascular system that include oxalate druses. We have also observed remains of flower in the powder, such as spherical, echinate pollen grains (Figures 7 and 8). 


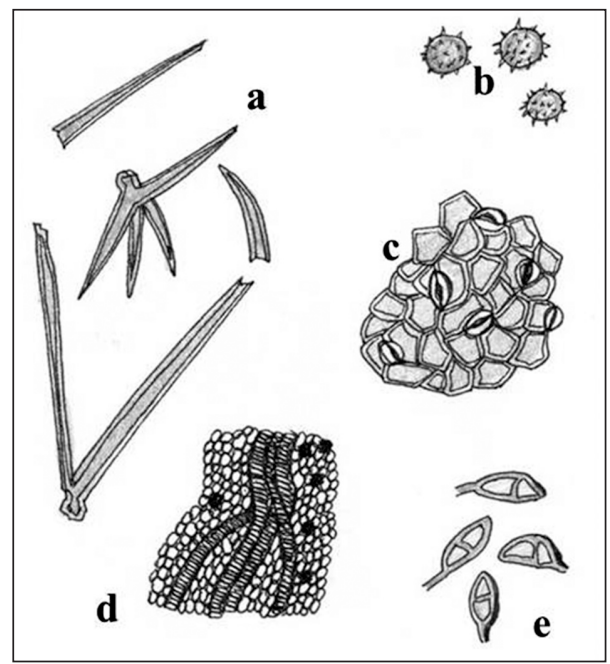

Figure 7. - Microscopic detail of Althaea officinalis L. root powder: a, starch grains; b, mucilage cells; c, fibres; $\mathrm{d}$, lignified parenchyma with bundles; e, vessel fragment.

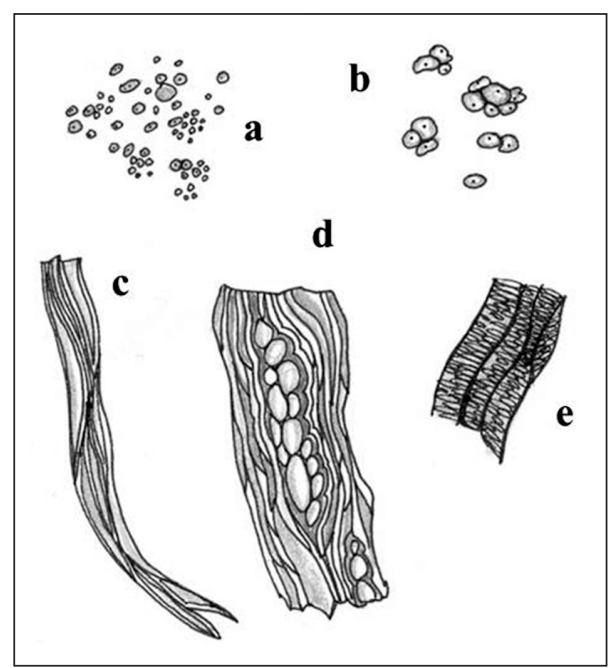

Figure 8. - Microscopic detail of Althaea officinalis L. leaf powder: a, star hair and its fragments; b, pollen grains; $\mathrm{c}$, lower epidermis with stoma; d, vascular ring with oxalate crystals; e, Puccinia malvacearum teliospores.

\section{Malva sylvestris $\mathbf{L}$.}

Madrid: Ciudad Universitaria. Facultad de Medicina. Jardines abandonados al norte del edificio, 29.05.2012, Rosario Gavilán \& Laure-Anne Peyrat, MAF 171388

Frequent species in the area due to its requirements for high nitrogen levels. The microscopic observation of the flower powder showed acute hairs, spherical, echinate pollen grains, teliospores of Puccinia malvacearum -a typical parasite of Malva sylvestris that is very common in plants in the Ciudad Universitaria and also appears in the observation made of Althaea officinalis- and parts of subepidermis and mesophyll with oxalate druses (Figure 9).

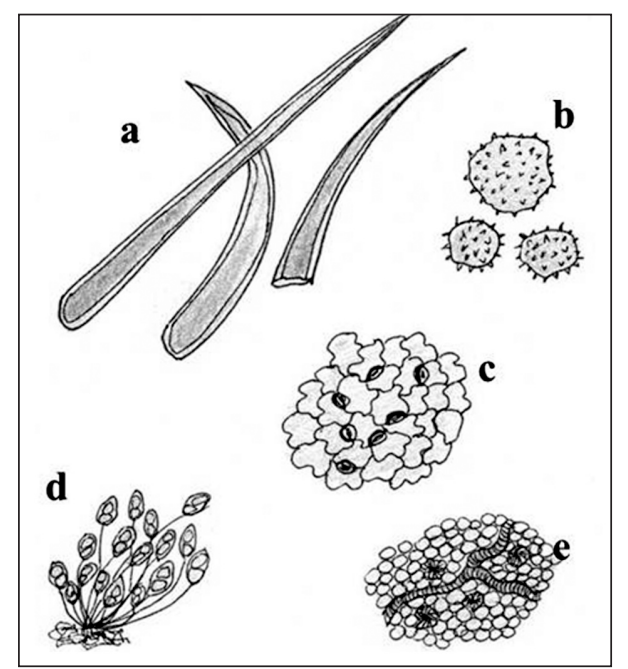

Figure 9. - Microscopic detail of Malva sylvestris L. flower powder: a, acute hairs; b, pollen grains; c, subepidermis with stoma; d, Puccinia malvacearum teliospores; e, mesophyll with oxalate druses.

\section{PAPAVERACEAE}

\section{Papaver rhoeas $\mathrm{L}$.}

Madrid: Ciudad Universitaria. Entre las facultades de Farmacia y Medicina. Lugares inultos, fuertemente nitrificados, $29.05 .2012,664 \mathrm{~m}$, Rosario Gavilán \& Laure-Anne Peyrat, MAF 171389.

Native of Europe (paleotemperate), it is a variable annual and ruderal plant that is very common in ruderal habitats in central Spain and also in the Ciudad Universitaria.

The microscopic observation of the flower (petals) powder showed fragments of anthers including pollen grains with scabrate exine and parts of epidermic and vascular tissue from petals (Figures 10 and 11). 


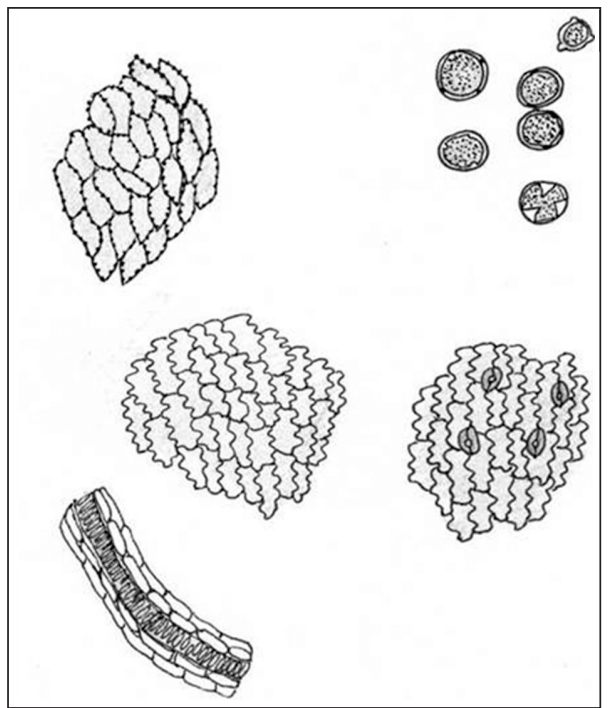

Figure 10. - Microscopic detail of Papaver rhoeas flower (petals) powder: a, anther fibrous layer fragment; $b$, pollen grains; c, petal epidermis; d, epidermis with stoma; e, spiral vessels.

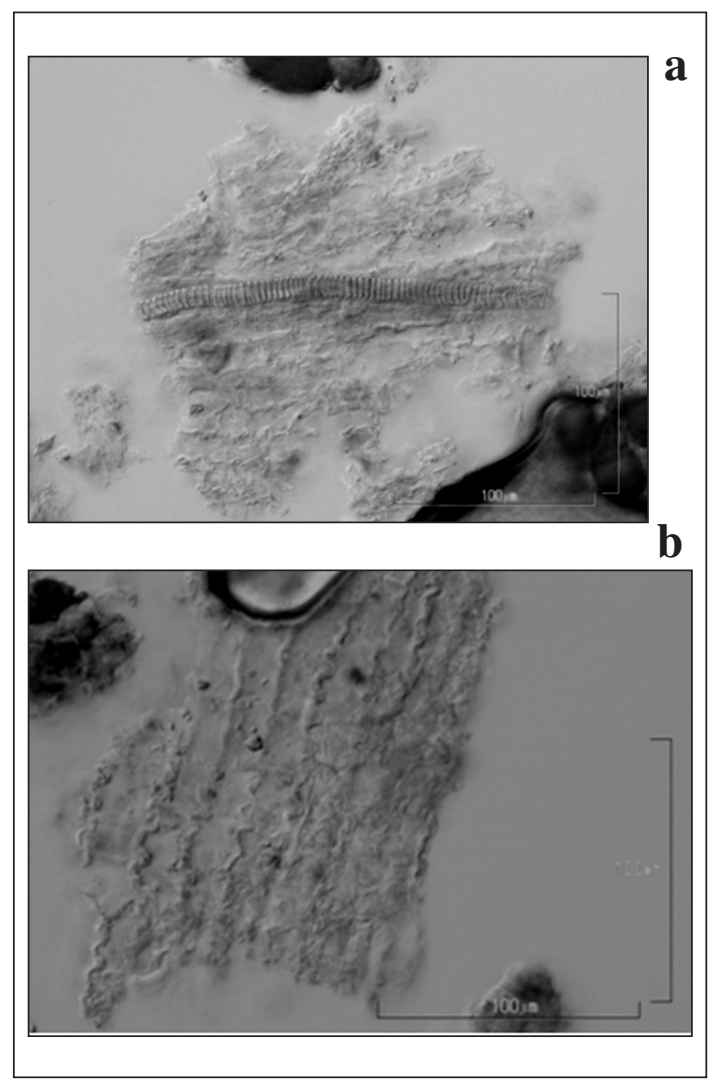

Figure 11.- Microscopic observation of Papaver rhoeas flower (petals) powder: a, petals epidermis; b, spiral vessels.

\section{ROSACEAE}

\section{Crataegus monogyna $\mathrm{L}$.}

Madrid: Ciudad Universitaria. Jardín Botánico Alfonso XIII. Cultivado, 29.05.2012, 664 m, Rosario Gavilán \& Laure-Anne Peyrat, MAF 171385 .

This plant is a species of hawthorn native to Europe, northwest Africa and western Asia. It is a spiny low tree that grows in borders and deciduous forests. We have found it cultivated in the Alfonso XIII Botanical Garden although it was cited as spontaneous in a previous paper (GAVILÁN \& al., 1993).

The microscopic observation of the flowers showed straight hairs, anther endothecium, striate pollen grains, and parts of epidermis containing oxalate druses (Figure 12).

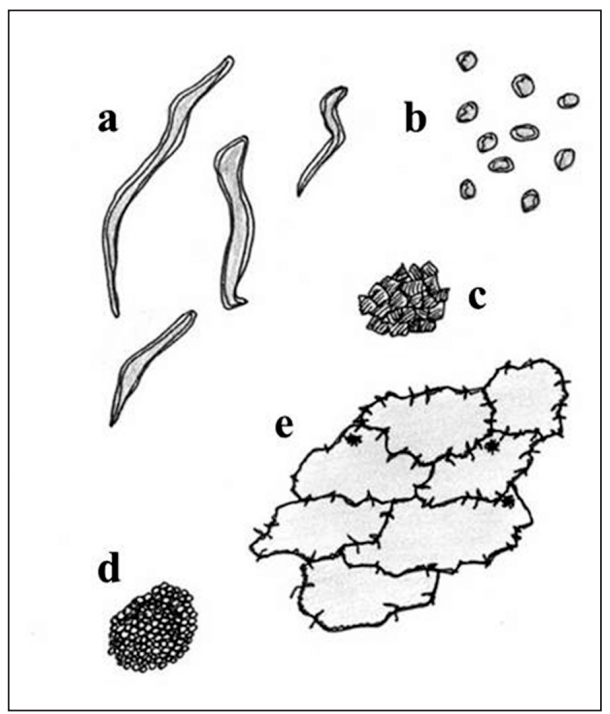

Figure 12. - Microscopic detail of Crataegus monogyna L. flower powder: a, calyx hairs; b, pollen grains; c, anther endothecium; $d$, lower epidermis containing oxalate druses; e, cuticular striated cells with septum walls.

\section{Fragaria vesca $\mathrm{L}$.}

Madrid: Ciudad Universitaria. Facultad de Medicina. Jardines abandonados al norte del edificio, 29.05.2012, Rosario Gavilán \& Laure-Anne Peyrat, MAF 171386. 


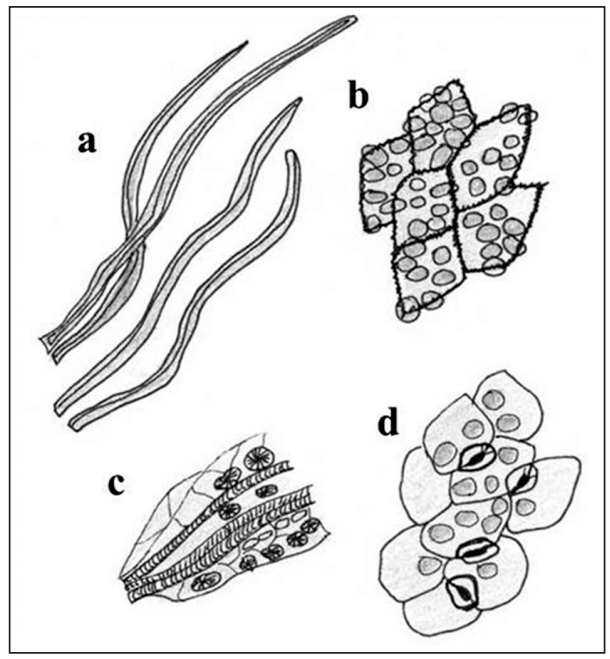

Figure 13. - Microscopic detail of Fragaria vesca leaf powder: a, hairs; b, palisade tissue and upper leaf epidermis; c, vascular tissue with oxalate druses and crystals; d, lower leaf epidermis with stoma.
This plant is a perennial native of the northern temperate regions of Eurasia and North America. In Spain it is common to find it forming part of the deciduous forest herb layer, since it requires some humidity. We have found it in more or less abandoned gardens that received some water during the whole year.

The microscopic observation of the leaf powder showed hairs and parts of epidermis or vascular tissue with oxalate druses (Figure 13).

\section{ACKNOWLEDGEMENTS}

We wish to thank Prudence Brooke-Turner for revising the English text. This research has been funded by the Madrid Regional Government (REMEDINAL2 Project: S2009/AMB1783) and the Spanish National Science Ministry, MICINN (BIOALPI Project: CGL 2008-904/BOS).

\section{REFERENCES}

Akerele, O., Heywood, V. \& Synge, H. - 1991 - The Conservation of Medicinal Plants - Cambridge Univ. Press, Cambridge.

Anonymous -2007-2009- European Pharmacopoeia, 6th edition. Monogr. vols. 0-8 - Europ. Dir. Qual. Med. Health Care, Strasbourg.

Bodeker, G. -2002- Medicinal Plants: Towards Sustainability and Security - Green College, Oxford.

Castroviejo, S. \& al. (Eds.) - 1986-2010 - Flora iberica R. Jard. Bot. CSIC, Madrid.

Cutler, D.F., Botha, T. \& Stevenson, D.W. -2008 - Plant Anatomy: An Applied Approach - Wiley-Blackwell.

Eschrich, W. -2009 - Pulver-Atlas der Drogen der deutschsprachigen Arzneibücher - Deust. Apot., Verlag.

Font Quer, P. - 2002 - Plantas Medicinales. El Dioscórides renovado - Ed. Labor, S.A., Madrid.

Fernández-González, F. — 1991 - La vegetación del valle del Paular (Sierra de Guadarrama, Madrid), 1 — Lazaroa 12: 153-272.

Galán, A. - in press - Taraxacum - In: Castroviejo, S. \& al. (Eds.). Flora ibérica. R. Jard. Bot. CSIC, Madrid.

García Antón, M. \& Génova Fúster, M.M. -1985- Aportaciones a la flora matritense - Lazaroa 8: 387-388.
Gavilán, R., Echevarría, J.E. \& Casas, I. -1992- Contribución al catálogo florístico de la Ciudad Universitaria (Madrid, España) - Bot. Compl. 18: 175-201.

Gavilán \& Molina, A. - 1992 - Sobre Opuntia phaeacantha Engelmann en España - An. Jard. Bot. Madrid 50(1): 118-119.

Hamilton, A.C. - 2004- Medicinal plants, conservation and livelihoods - Biodiv. Cons. 13: 1477-1517.

Izco, J. - 1979 - La flora y la vegetación del Monte de El Pardo y de la Casa de Campo - Bol. R. Soc. Esp. Hist. Nat. (Biol.) 77: 101-116.

Izco, J. \& Pangua, E. - 1986 - Aportaciones a la flora de Madrid: algunos neófitos interesantes - Lazaroa 8: 373-378.

Molina, A., Gavilán, R., Echevarría, J.E. \& Casas, I. 1991 - Notas sobre flora alóctona ibérica - Rivasgodaya 6: 145-148.

Pignatti, S. - 1982 - Flora d'Italia - Edagricola, Bologna.

Sultan, H.A.S., Abu Elreish, B.I. \& Yagi, S.M. -2010Anatomical and Phytochemical Studies of the Leaves and Roots of Urginea grandiflora and Pancratium tortuosum - Ethnobot. Leaf. 14: 826-35

Tutin, S. \& al. (Eds.) -1964-1993 - Flora Europaea Cambridge Univ. Press, Cambridge. 